\title{
UFGE 7031 and UFGE 7080 Gerbera Cultivars
}

\author{
Zhanao Deng ${ }^{1}$ and Brent K. Harbaugh \\ University of Florida/Institute of Food and Agricultural Sciences, \\ Environmental Horticulture Department, Gulf Coast Research and Education \\ Center, 14625 County Road 672, Wimauma, FL 33598
}

Additional index words. Gerbera hybrida, Gerbera jamesonii, plant breeding

Cultivated gerbera (Gerbera hybrida, Asteraceae Dumont) is one of the most important floricultural crops in the United States and worldwide (Behnke, 1984; Rogers and Tjia, 1990). It is well accepted in the cut flower and potted plant markets and can also be grown as a patio, garden, or landscape plant. Gerbera breeding over the past several decades has been focused primarily on developing cultivars for cut flower production or for small flowering pot plants to be used in flower beds (Behnke, 1984; Rogers and Tjia, 1990). Cut flower cultivars require gerbera flowers with long peduncles (greater than $50 \mathrm{~cm}$ ). The majority of the pot gerbera cultivars have been developed for production in 15-cm-diameter or smaller containers; thus, these cultivars produce compact plants and flowers with short peduncles (less than $30 \mathrm{~cm}$ ) (Dole and Wilkins, 1999). Recently, interest in producing gerberas in large (20-cm-diamter or larger) containers for indoor or outdoor use has increased [O. Nissen (Sunshine Carnations State, Inc.) and J. Mazat (Ball Horticultural Company), personal communication]. There has been a severe shortage of cultivars suitable for such uses (Channel, 2005). Greenhouse growers and nurseries often rely on two strategies to produce gerberas for this emerging market. One method uses cut flower cultivars and growth retardants to shorten the flower peduncles. However, finished plants often have few flowers and peduncles are still too tall for the pot size. Other growers have tried to use small cultivars, but finished gerbera plants tend to be too small and do not satisfactorily fill up the containers.

Previously we developed and released six gerbera cultivars for use in large containers (Deng and Harbaugh, 2010). These cultivars are marketed under the Funtastic ${ }^{\mathrm{TM}}$ series (Ball Horticultural Company) and have displayed exceptional heat tolerance in industry and/or university trials (Siktberg, 2012). Some of these cultivars were selected as "Best of the Best" in the University of Georgia garden trials ( $<$ http://ugatrial.hort. uga.edu/index.cfm $>$ ) and as top performers in the Ohio State University garden trials (Anonymous, 2011). The current series consists of five flower colors (white, light pink, yellow, orange, and orange-red). Additional cultivars are needed to expand the plant palette in this series. Like in other flower crops, continuous introduction of new cultivars with improved or novel horticultural characteristics may serve as a driving force for commercial production and consumer consumption (Behnke, 1984; Rogers and Tjia, 1990).

UFGE 7031 and UFGE 7080 were selected and tested specifically for the largecontainer flower market. These cultivars produce large plants with large attractive flowers and appropriate peduncle heights for use in larger containers. These gerberas also express moderate to high levels of resistance to powdery mildew, the most common and important disease in gerbera production and gardening (Chase, 2001; Moyer and Peres, 2008).

\section{Origin}

UFGE 7031 resulted from a cross between selections UFGE 5004 and UFGE 5015 (Fig. 1) and was initially selected in late 2007 for its powdery mildew resistance, attractive flower color, and large flower size. UFGE 5004 was an offspring of breeding lines UFGE 31-19 and UFGE 5-23 that were crossed in 2004 and was selected in 2005. UFGE 5015 was a progeny of the cross between commercial cultivar Sunburst Fuchsia (non-patented) and breeding line UFGE 3714 and was selected in 2005.

UFGE 7080 was derived from a cross between selections UFGE 5-23 and UFGE 20-1 that was made in Spring 2003 (Fig. 1). UFGE 7080 was selected in 2004 for its plant growth habit, dark foliage, and large, bicolored flowers.

UFGE 5-23, UFGE 31-19, and UFGE 3714 were selected out of $\approx 2000$ progeny from the seeds donated by Sunshine State Carnations, Inc. (Hobe Sound, FL). UFGE 5-23 and UFGE 31-19 were selected for their moderate or high level of resistance to powdery mildew resistance, respectively (Z. Deng, unpublished data).

\section{Description}

Descriptions of color [e.g., Royal Horticultural Society (RHS) 200B] for plant parts are based on comparison with the Royal Horticultural Society Color Chart (Royal Horticultural Society, 1986). Plants used for describing color were 3 -months old and were started from tissue culture liners and grown in 20 -cm-diameter containers in a greenhouse covered with a $30 \%$ shading cloth.

Mature plants of UFGE 7031 were $50 \mathrm{~cm}$ tall and $60 \mathrm{~cm}$ wide (Table 1; Fig. 2). Leaves were simple and pinnately lobed, with deep lobes in the basal third and shallow lobes from the central third up to the top third. The upper and lower leaf surfaces were medium green, RHS 147A and RHS 147B, respectively. Flowers (Table 1; Fig. 3) are of the single type and have a diameter of 11.1 to $13.7 \mathrm{~cm}$. The upper and lower sides of the outer ray florets were orange-red (RHS 30B) and yellow-orange (RHS 32C/D), respectively. Disc florets were orange-red (RHS $33 \mathrm{~A})$. Peduncles were 36 to $45 \mathrm{~cm}$ in height.

Mature plants of UFGE 7080 were $53 \mathrm{~cm}$ tall and $65 \mathrm{~cm}$ wide (Table 1; Fig. 4). Leaves were simple and pinnately lobed, with deep lobes in the basal third, shallow lobes in the central third, and no obvious lobes near the top third. The upper leaf surface was medium green (RHS 146A). Flowers (Table 1; Fig. 5) are single and have a diameter of 11.1 to $11.9 \mathrm{~cm}$. The upper side of the outer ray florets was bicolored, yellow (RHS 9A) near the base and transitioning to orange (RHS 25A) toward the apex. The lower surface was yellow (RHS 12B). Disc florets were orange (RHS 28B). Peduncles of mature flowers were 43 to $52 \mathrm{~cm}$ in height.
Received for publication 20 Feb. 2013. Accepted for publication 13 Mar. 2013.

We thank Sunshine State Carnations, Inc. and the Fred C. Gloeckner Foundation for providing financial support for some of the breeding activities toward the development of these gerbera cultivars, and Gail Bowman, Joyce Jones, Richard Kelly, and Nancy West for their excellent technical support. Agri-Starts, Inc. established tissue culture stock for these gerberas and donated the tissue culture liners for all the experiments reported herein.

${ }^{1}$ To whom reprint requests should be addressed; e-mail zdeng@ufl.edu.
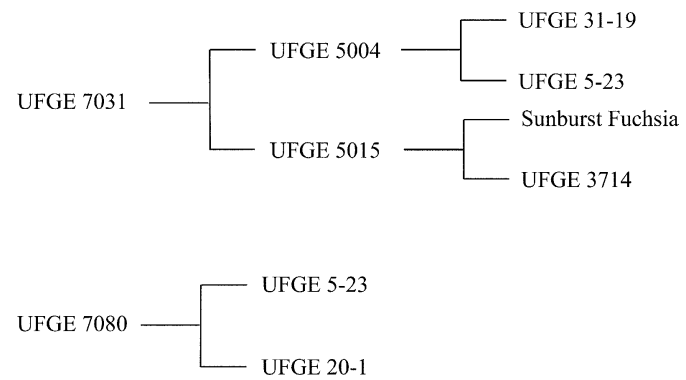

Fig. 1. Pedigree of UFGE 7031 and UFGE 7080. 
Table 1. Summary of major plant and flower characteristics of UFGE 7031 and UFGE 7080 based on Expts. 1 to 3.

\begin{tabular}{lcc}
\hline & UFGE 7031 & UFGE 7080 \\
\hline Plant size (height $\times$ width) $(\mathrm{cm})^{\mathrm{z}}$ & $50 \times 60$ & $53 \times 65$ \\
Flower form & Single & Single \\
Flower color (ray florets) & Orange-red & Bicolored, yellow and orange \\
Eye color (disc florets) & Orange-red & Orange \\
Flower size (diameter, cm) & 10.3 to 13.7 & 10.5 to 11.9 \\
Peduncle height $(\mathrm{cm})$ & 36 to 45 & 43 to 52 \\
\hline
\end{tabular}

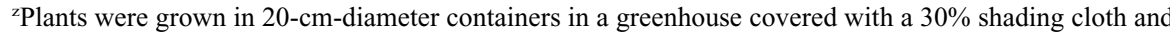
were 3 months old grown from tissue culture liners. Plant growth regulators were not applied in these experiments.

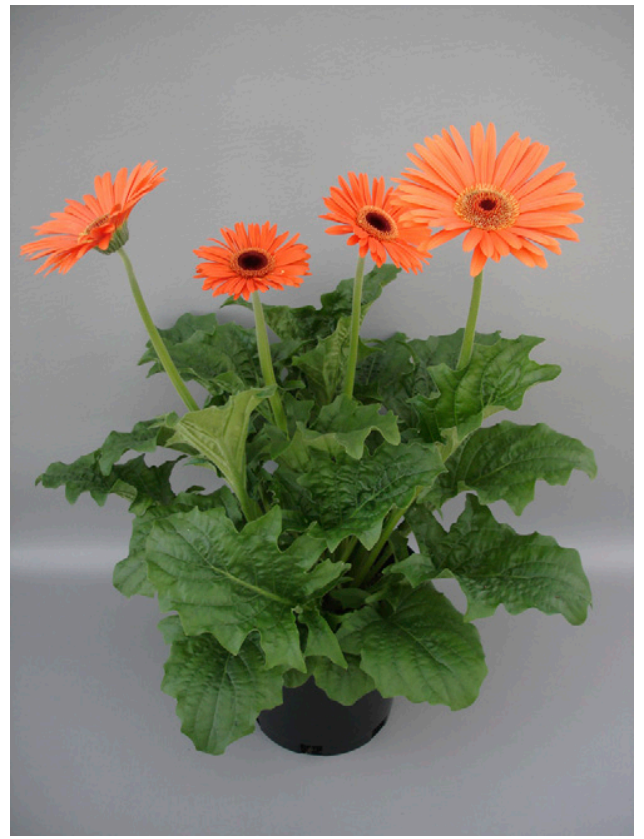

Fig. 2. A single plant ( $\approx 10$ weeks old) of UFGE 7031 grown from a single tissue culture liner in a 20 -cmdiameter container.

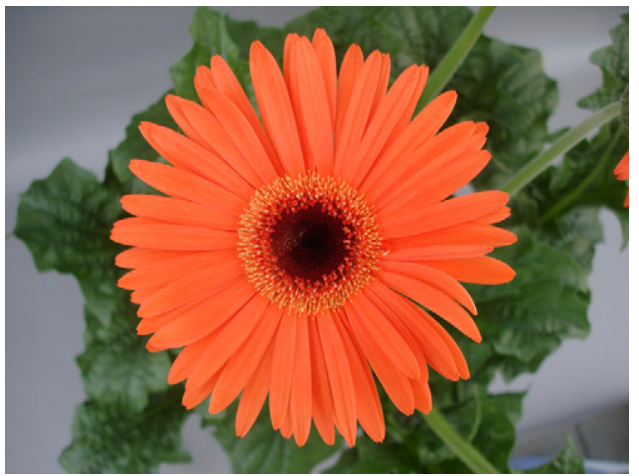

Fig. 3. Flower of UFGE 7031.

\section{Horticultural Characteristics}

Three experiments (Expts. 1 to 3 ) were conducted in the greenhouse to evaluate horticultural characteristics, including plant quality, days to flower, flower size, flower quality, peduncle length, and flower count. In Expt. 1, tissue culture liners (Agri-Starts, Apopka, FL) were transplanted on 9 Dec. 2008 into 20-cm-diameter containers filled with commercial potting mix Fafard 3B (Conrad Fafard, Inc., Agawam, MA) amended with the controlled-release fertilizer Osmocote $(15 \mathrm{~N}-3.9 \mathrm{P}-10 \mathrm{~K}, 5$ to 6 months; Scotts Co., Marysville, $\mathrm{OH})$ at $5.28 \mathrm{~kg} \cdot \mathrm{m}^{-3}$ and the trace element fertilizer MicroMax (Scotts Co.) at $1.05 \mathrm{~kg} \cdot \mathrm{m}^{-3}$. Potted plants were grown on metal benches at $\approx 46 \mathrm{~cm}$ spacing between pots in a greenhouse in Wimauma, FL. Irrigation was through drip tubes. Temperatures inside the greenhouse ranged from $18{ }^{\circ} \mathrm{C}$ (night) to $33{ }^{\circ} \mathrm{C}$ (day). Two additional hours of incandescent photoperiodic lighting were provided between 9 Dec. 2008 and 17 Mar. 2009. Fungicides and insecticides were applied as needed to control powdery mildew (Podosphaera fusca) (Moyer and Peres, 2008) and western flower thrips (Frankliniella occidentalis) (Price et al., 2003). The number of flowers produced per potted plant was recorded weekly from 20 Jan. 2009 through 17 Mar. 2009. The number of days from transplanting to the opening of the third flower was recorded as the production time needed to produce marketable potted flowering plants. Flower quality was rated on a 1 to 5 scale: $1=$ very poor; $3=$ fair, some blemishes, but acceptable; and $5=$ excellent, bright, uniform, and no blemishes. Plant quality was rated on 17 Feb. 2009 using a 1 to 5 scale: $1=$ few leaves or long petioles, container surface visible, very poor and unacceptable as flowering potted plants; 3 = fair and marketable; and $5=$ excellent, full, symmetrical, attractive flowering plants.

Expt. 2 was conducted in Aug. through Nov. 2009. Gerbera tissue culture liners were transplanted on 13 Aug. 2009 into 20-cmdiameter plastic containers filled with Fafard 3B potting mix (Conrad Fafard) amended as Expt. 1. Potted plants were grown as described in Expt. 1. The greenhouse was covered with aluminum shading cloth (Aluminet ${ }^{\circledR}$; Signature Supplies, Inc., Lakeland, FL) with $\approx 30 \%$ light exclusion. Temperatures in the greenhouse were between $21{ }^{\circ} \mathrm{C}$ (night) and $35^{\circ} \mathrm{C}$ (day). Additional photoperiodic lighting (incandescent, $\approx 5 \mu \mathrm{mol} \cdot \mathrm{m}^{-2} \cdot \mathrm{s}^{-1}, 2 \mathrm{~h}$ ) began on 15 Sept. 2009. The number of new flowers produced per plant was recorded weekly from 25 Sept. 2009 through 20 Nov. 2009. Flower and plant quality were rated as Expt. 1 .

Expt. 3 was conducted in Apr. through Aug. 2012. Tissue culture liners (Agri-Starts) were transplanted on 4 Apr. 2012 into 20-cmdiameter plastic containers filled with amended Fafard 3B potting mix. Growing conditions were similar to those described for Expt. 2 . The number of flowers produced per potted plant was recorded weekly from 12 June through 31 July 2012. Flower and plant quality were rated as in Expt. 1.

Two types of commercial cultivars were included for comparison. The first were cut flower cultivars that were used to produce gerberas in large containers (Sunshine States Carnations, Inc., Hobe Sound, FL), including 'Bimini' and 'Pensacola'. 'Funtastic ${ }^{\mathrm{TM}}$ Fire Orange' (UFGE 4141) or 'Funtastic ${ }^{\mathrm{TM}}$ Canary' (UFGE 7032) were also used as checks because these cultivars were developed and recently released for use in large containers (Deng and Harbaugh, 2010). The experimental design was a randomized complete block design with five (Expt. 1), eight (Expt. 2), or six (Expt. 3) replications. The experimental unit was a single containerized plant grown from one tissue culture liner. Experimental data were analyzed using PROC GLM in the SAS software (SAS Inst., Cary, NC) and mean separation was 


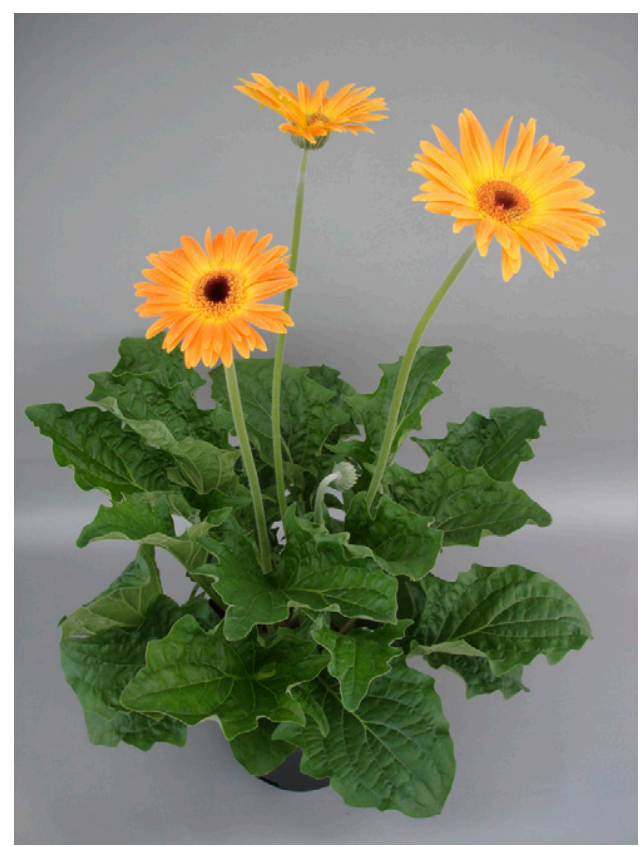

Fig. 4. UFGE 7080 plant $(\approx 10$ weeks old) grown from a single tissue culture liner in a 20 -cm-diameter container.

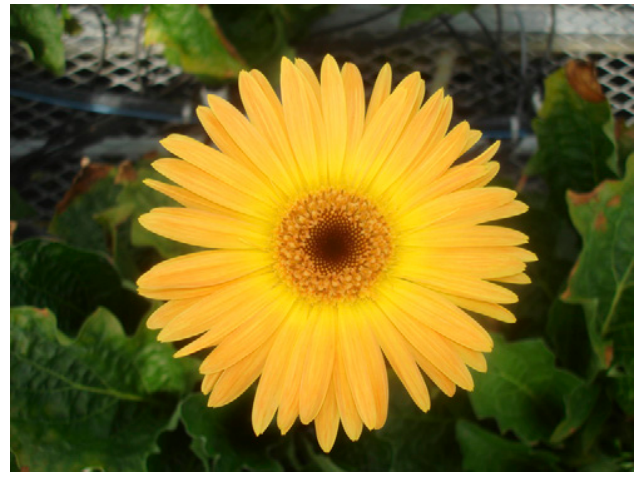

Fig. 5. Flower of UFGE 7080.

done using the least significant difference (LSD) at $P=0.05$.

UFGE 7031. Plants of this cultivar opened third flowers $\approx 82 \mathrm{~d}$ after transplanting in December (Expt. 1) or April (Expt. 3) and did so $\approx 61 \mathrm{~d}$ after transplanting in August (Expt. 2) (Table 2). The time to the third open flower was $\approx 13 \mathrm{~d}$ shorter for UFGE 7031 than for 'Bimini' in Expt. 1 and appeared to be $4 \mathrm{~d}$ shorter (not significantly different) in Expt. 2. The time to the third open flower was $\approx 19 \mathrm{~d}$ shorter for UFGE 7031 than for 'Pensacola' in Expt. 2. However, the time to the third open flower was $\approx 8 \mathrm{~d}$ longer for UFGE 7031 than for 'Funtastic ${ }^{\mathrm{TM}}$ Fire Orange'. The time to the third open flower was also $\approx 12 \mathrm{~d}$ longer for UFGE 7031 than for 'Funtastic ${ }^{\mathrm{TM}}$ Canary' in Expt. 1 and appeared to be $4 \mathrm{~d}$ longer in Expts. 2 and 3.

Peduncles of UFGE 7031 were 36.0 to $43.7 \mathrm{~cm}$, similar to the peduncle length of 'Funtastic ${ }^{\top M}$ Canary', but $\approx 18$ to $22 \mathrm{~cm}$ shorter than that of 'Bimini' or 'Pensacola',
UFGE 7031 produced similar numbers of flowers compared with 'Bimini' in Expt. 1, but $66 \%$ more flowers than 'Bimini' and $172 \%$ more flowers than 'Pensacola' in Expt. 2 (Table 3). Compared with 'Funtastic ${ }^{\mathrm{TM}}$ Fire Orange', UFGE 7031 was less productive with $25 \%$ to $32 \%$ lower flower counts in Expts. 1 and 2. UFGE 7031 produced 25\% fewer flowers than 'Funtastic ${ }^{\mathrm{TM}}$ Canary' in Expt. 1, but it was comparable to 'Funtastic ${ }^{\mathrm{TM}}$ Canary' in flower production in Expts. 2 and 3.

$U F G E$ 7080. Plants of this cultivar opened third flowers $\approx 92 \mathrm{~d}$ after transplanting in Dec. 2008 (Expt. 1) and $\approx 74 \mathrm{~d}$ after transplanting in Aug. 2009 or Apr. 2012 (Expt. 2 or 3) (Table 2). Thus, time to THE third open flower for UFGE 7080 was similar to the time to the third open flower for 'Bimini' or 'Pensacola', but it was 18 to $23 \mathrm{~d}$ longer than the time to the third open flower for 'Funtastic ${ }^{\mathrm{TM}}$ Fire Orange' or 'Funtastic ${ }^{\mathrm{TM}}$ Canary' in two of three experiments (Expts. 1 and 2).

Peduncles of UFGE 7080 were 43.2 to $52.0 \mathrm{~cm}, 10$ to $15 \mathrm{~cm}$ shorter than the peduncle length of 'Bimini' or 'Pensacola', but similar to the peduncle length of 'Funtastic ${ }^{\mathrm{TM}}$ Fire Orange' (Table 2). Flowers of UFGE 7080 were large, $\approx 11.1$ to $11.9 \mathrm{~cm}$ in diameter. This size is similar to the flower size of 'Funtastic' Canary' in Expts. 1 and 2 but $\approx 2 \mathrm{~cm}$ larger than the flower size of 'Funtastic ${ }^{\mathrm{TM}}$ Canary' in Expt. 3 (Table 2). Flowers of UFGE 7080 were very attractive and received a quality rating of 3.9 to 4.3 in three experiments, which was similar to the flower quality rating of 'Funtastic' ${ }^{\mathrm{TM}}$ Canary' in Expt. 1, lower than that of 'Funtastic 'TM Canary' in Expt. 2, but higher than that of 'Funtastic ${ }^{\mathrm{TM}}$ Canary' in Expt. 3 (Table 2). Flower quality rating of UFGE 7080 was similar to that of 'Funtastic ${ }^{\mathrm{TM}}$ Fire Orange' in both Expts. 1 and 2. Plant quality rating was 3.8 to 4.9 for UFGE 7080 , higher than the plant quality rating for 'Bimini' or 'Pensacola', and comparable to, or even higher than, the quality rating for 'Funtastic ${ }^{\mathrm{TM}}$ Fire Orange' and 'Funtastic ${ }^{\mathrm{TM}}$ Canary'. Plant quality rating was generally higher for UFGE 7080 than for UFGE 7031.

UFGE 7080 produced similar numbers of flowers with 'Bimini' or 'Pensacola' in Expts. 1 and 2 (Table 3). Although it was similarly productive as 'Funtastic ${ }^{\mathrm{TM}}$ Canary' in one experiment (Expt. 3), UFGE 7080 was significantly less productive than 'Funtastic ${ }^{\mathrm{TM}}$ Fire Orange' and Funtastic ${ }^{\mathrm{TM}}$ Canary' in two experiments (Expts. 1 and 2).

\section{Powdery Mildew Susceptibility}

Five experiments were conducted to assess the resistance (or susceptibility) level of UFGE 7031 and UFGE 7080 to powdery mildew. Expts. 4, 6, and 7 were done in parallel with Expts. 1 to 3: gerbera tissue culture liners, the potting mix, irrigation, and fertilization were the same as Expts. 1 to 3, but the potted plants were grown under a plastic tunnel within a screen house with $\approx 50 \%$ light exclusion rather than in the greenhouse. No temperature control or additional photoperiodic lighting was provided in the screen 
house. Plants were subjected to natural powdery mildew disease pressures, and fungicides were not applied throughout the experiments. In Expt. 4, powdery mildew severity on gerbera plants was assessed at Weeks 6 (21 Jan. 2009), 8 (4 Feb. 2009), 10 (18 Feb. 2009), 12 (4 Mar. 2009), and 14 (18 Mar. 2009) after transplanting using a scale of 1 to 10 as described by Hausbeck et al. (2002). In Expt. 6, powdery mildew severity was assessed at Weeks 6 (1 Oct. 2009), 8 (15 Oct. 2009), and 10 (29 Oct. 2009) after transplanting. In Expt. 7, powdery mildew severity was assessed at Weeks 6 (25 May 2012), 8 (29 June 2012), 10 (20 July 2012), and 12 (3 Aug. 2012) after transplanting. In addition, newly opened flowers were recorded weekly over a period of 6 to 9 weeks for plants under natural powdery mildew disease pressures.

Expts. 5 and 8 were conducted using mature, flowering gerbera plants that were grown as described in Expts. 1 and 3. These plants were grown in the greenhouse and subjected to natural powdery mildew disease pressures in the greenhouse. In Expt. 5, powdery mildew severity was evaluated on $24 \mathrm{Apr}$., 8 May, 22 May, and 11 June 2009, and in Expt. 8 , powdery mildew severity was evaluated on 3 Aug. 2012.

A randomized complete block design was used in these experiments with five (Expt. 4), five (Expt. 5), six (Expt. 6), four (Expt. 7), or six (Expt. 8) replications. The experimental unit was a single containerized plant. Similarly, 'Funtastic ${ }^{\mathrm{TM}}$ Fire Orange', 'Funtastic ${ }^{\mathrm{TM}}$ Canary', 'Bimini', and/or 'Pensacola' were included as control cultivars. Powdery mildew severity rating data from the last evaluation in each experiment were analyzed using PROC GLM in the SAS software and mean separation was done using the LSD at $P=0.05$.

In Expt. 4, powdery mildew symptoms first appeared on 'Bimini' plants 8 weeks after transplanting, and the average severity rating of all entries increased rapidly in the next 6 weeks: from 1.7 on $18 \mathrm{Feb}$. to 4.3 on 4 Mar. and then to 6.5 on 18 Mar. Similarly, severe powdery mildew was observed in Expt. 5 between Apr. and June 2009. The overall average powdery mildew severity rating was 4.9 on 24 Apr., 5.8 on 8 May, 5.4 on 22 May, and 5.3 on 11 June 2009. Plants of 'Bimini' and 'Pensacola' were highly susceptible to powdery mildew in these experiments. Powdery mildew was much less severe in Expts. 6, 7, and 8 .

Plants of UFGE 7031 received the lowest powdery mildew severity ratings in all five experiments, and its rating was below 3.0 in four experiments (Table 4). These results indicate a high level of powdery mildew resistance in this cultivar. Under natural powdery mildew pressures, UFGE 7031 produced similar numbers of flowers with 'Funtastic ${ }^{\mathrm{TM}}$ Fire Orange' in Expts. 4, 5, and 7, but fewer flowers in Expt. 6 (Table 5). UFGE 7031 produced similar numbers of flowers with 'Funtastic ${ }^{\mathrm{TM}}$ Canary' in two experiments (Expts. 5 and 7) and fewer flowers in another two experiments (Expts. 4 and 6).

Table 2. Horticultural characteristics of UF 7031 and UFGE 7080 in comparison with 'Bimini', 'Pensacola', 'Funtastic ${ }^{\mathrm{TM}}$ Fire Orange', and/or 'Funtastic ${ }^{\mathrm{TM}}$ Canary' in three experiments conducted in Wimauma, FL (2009 and 2012).

\begin{tabular}{|c|c|c|c|c|c|}
\hline Cultivars & $\begin{array}{c}\text { Days to third } \\
\text { open flower (no.) }\end{array}$ & $\begin{array}{l}\text { Peduncle } \\
\mathrm{ht}(\mathrm{cm})\end{array}$ & $\begin{array}{c}\text { Flower } \\
\text { size }(\mathrm{cm})\end{array}$ & $\begin{array}{l}\text { Flower } \\
\text { quality }^{z}\end{array}$ & $\begin{array}{l}\text { Plant } \\
\text { quality }\end{array}$ \\
\hline \multicolumn{6}{|c|}{ Expt. 1 (Dec. 2008 to Mar. 2009) } \\
\hline UFGE 7031 & $82.0 \mathrm{bc}^{\mathrm{x}}$ & $36.0 \mathrm{~d}$ & $13.7 \mathrm{a}$ & $3.9 \mathrm{c}$ & $3.0 \mathrm{c}$ \\
\hline UFGE 7080 & $91.6 \mathrm{ab}$ & $43.2 \mathrm{~b}$ & $11.9 \mathrm{bc}$ & $4.2 \mathrm{bc}$ & $4.2 \mathrm{a}$ \\
\hline Bimini & $95.0 \mathrm{a}$ & $58.5 \mathrm{a}$ & $11.2 \mathrm{c}$ & $5.0 \mathrm{a}$ & $3.4 \mathrm{bc}$ \\
\hline Funtastic $^{\mathrm{TM}}$ Fire Orange & $74.2 \mathrm{~cd}$ & $41.6 \mathrm{~b}$ & $12.9 \mathrm{a}$ & $3.8 \mathrm{c}$ & $3.8 \mathrm{ab}$ \\
\hline Funtastic ${ }^{\mathrm{TM}}$ Canary & $69.6 \mathrm{~d}$ & $38.6 \mathrm{c}$ & $11.0 \mathrm{c}$ & $4.8 \mathrm{ab}$ & $3.8 \mathrm{ab}$ \\
\hline $\operatorname{LSD}(P \leq 0.05)$ & 10.4 & 2.2 & 1.0 & 0.7 & 0.7 \\
\hline \multicolumn{6}{|c|}{ Expt. 2 (Aug. to Nov. 2009) } \\
\hline UFGE 7031 & $60.5 \mathrm{bc}$ & $43.7 \mathrm{c}$ & $11.3 \mathrm{ab}$ & $3.9 \mathrm{~b}$ & $4.5 \mathrm{ab}$ \\
\hline UFGE 7080 & $74.3 \mathrm{a}$ & $52.0 \mathrm{~b}$ & $11.2 \mathrm{ab}$ & $3.9 \mathrm{c}$ & $4.9 \mathrm{a}$ \\
\hline Bimini & $64.5 \mathrm{~b}$ & $61.5 \mathrm{a}$ & $10.6 \mathrm{bc}$ & $4.8 \mathrm{ab}$ & $4.1 \mathrm{~b}$ \\
\hline Pensacola & $79.5 \mathrm{a}$ & $62.5 \mathrm{a}$ & $11.2 \mathrm{ab}$ & $4.3 \mathrm{bc}$ & $4.3 \mathrm{~b}$ \\
\hline Funtastic $^{\mathrm{TM}}$ Fire Orange & $52.9 \mathrm{c}$ & $51.8 \mathrm{~b}$ & $11.6 \mathrm{a}$ & $4.2 \mathrm{c}$ & $4.1 \mathrm{~b}$ \\
\hline Funtastic $^{\mathrm{TM}}$ Canary & $56.0 \mathrm{bc}$ & $37.9 \mathrm{~d}$ & $10.0 \mathrm{c}$ & $4.8 \mathrm{ab}$ & $4.8 \mathrm{a}$ \\
\hline $\operatorname{LSD}(P \leq 0.05)$ & 8.9 & 4.3 & 0.7 & 0.5 & 0.5 \\
\hline \multicolumn{6}{|c|}{ Expt. 3 (Apr. to July 2012) } \\
\hline UFGE 7031 & $81.3 \mathrm{a}$ & $36.5 \mathrm{~b}$ & $11.1 \mathrm{a}$ & $4.1 \mathrm{ab}$ & $2.9 \mathrm{~b}$ \\
\hline UFGE 7080 & $72.5 \mathrm{~b}$ & $45.8 \mathrm{a}$ & $11.1 \mathrm{a}$ & $4.3 \mathrm{a}$ & $3.8 \mathrm{a}$ \\
\hline Funtastic ${ }^{\mathrm{TM}}$ Canary & $77.0 \mathrm{ab}$ & $36.5 \mathrm{~b}$ & $9.2 \mathrm{~b}$ & $3.9 \mathrm{~b}$ & $3.8 \mathrm{a}$ \\
\hline $\operatorname{LSD}(P \leq 0.05)$ & 7.4 & 4.3 & 0.7 & 0.3 & 0.6 \\
\hline
\end{tabular}

${ }^{\mathrm{z}}$ Flower quality was rated on a 1 to 5 scale: $1=$ very poor; $3=$ fair, some blemishes, but acceptable; and $5=$ excellent, bright, uniform, and no blemishes.

${ }^{y}$ No plant growth regulators were used in these experiments, and plant quality was rated using a 1 to 5 scale: $1=$ few leaves or long petioles, container surface visible, very poor and unacceptable as flowering pot plants; 3 = fair and meeting the minimum standard for marketability; and $5=$ excellent, full, attractive, symmetrical plants.

${ }^{x}$ Values with the same letter within a column are not statistically different at $P \leq 0.05$.

LSD $=$ least significant difference.

Table 3. Number of flowers produced per potted plant of UFGE 7031 and UFGE 7080 in comparison with 'Bimini', 'Pensacola', 'Funtastic ${ }^{\mathrm{TM}}$ Fire Orange', and/or 'Funtastic ${ }^{\mathrm{TM}}$ Canary' in three experiments conducted in Wimauma, FL (2009 and 2012).

\begin{tabular}{lccc}
\hline Cultivars & $\begin{array}{c}\text { Expt. 1 (flowers counted } \\
\text { between Jan. } \\
\text { and Mar. 2009) }\end{array}$ & $\begin{array}{c}\text { Expt. 2 (flowers counted } \\
\text { between September } \\
\text { and Nov. 2009) }\end{array}$ & $\begin{array}{c}\text { Expt. 3 (flowers counted } \\
\text { between June } \\
\text { and July 2012) }\end{array}$ \\
\hline UFGE 7031 & $4.2 \mathrm{~b}^{\mathrm{z}}$ & $6.8 \mathrm{~b}$ & 8.0 \\
UFGE 7080 & $3.6 \mathrm{~b}$ & $3.4 \mathrm{~cd}$ & 9.7 \\
Bimini & $3.0 \mathrm{~b}$ & $4.1 \mathrm{c}$ & \\
Pensacola & $5.6 \mathrm{a}$ & $2.5 \mathrm{~d}$ & \\
Funtastic & & $10.0 \mathrm{a}$ & \\
Funtastic Fire Orange & $6.2 \mathrm{a}$ & $7.6 \mathrm{~b}$ & 10.0 \\
LSD $(P \leq 0.05)$ & 1.4 & 1.5 & $\mathrm{NS}$ \\
\hline
\end{tabular}

${ }^{\mathrm{z}}$ Values with the same letter within a column are not statistically different at $P \leq 0.05$.

LSD $=$ least significant difference; $\mathrm{NS}=$ not significantly different at $P \leq 0.05$.

Table 4. Powdery mildew severity on leaves of UFGE 70031 and UFGE 7080 in comparison with 'Bimini', 'Pensacola', 'Funtastic ${ }^{\mathrm{TM}}$ Fire Orange', and/or 'Funtastic ${ }^{\mathrm{TM}}$ Canary' in five experiments conducted in Wimauma, FL (2009 and 2012). ${ }^{\mathrm{z}}$

\begin{tabular}{|c|c|c|c|c|c|}
\hline Cultivars & $\begin{array}{c}\text { Expt. } 4 \\
\text { (Mar. 2009) }\end{array}$ & $\begin{array}{c}\text { Expt. 5 } \\
\text { (June 2009) }\end{array}$ & $\begin{array}{c}\text { Expt. } 6 \\
\text { (Oct. 2009) }\end{array}$ & $\begin{array}{c}\text { Expt. } 7 \\
\text { (Aug. 2012) }\end{array}$ & $\begin{array}{c}\text { Expt. } 8 \\
\text { (Aug. 2012) }\end{array}$ \\
\hline UFGE 7031 & $3.6 \mathrm{c}^{\mathrm{y}}$ & $2.7 \mathrm{c}$ & $1.7 \mathrm{~b}$ & $1.5 \mathrm{~b}$ & $1.0 \mathrm{~b}$ \\
\hline UFGE 7080 & $4.8 \mathrm{bc}$ & $4.0 \mathrm{c}$ & $3.7 \mathrm{a}$ & $3.0 \mathrm{a}$ & $1.7 \mathrm{ab}$ \\
\hline Bimini & $7.5 \mathrm{a}$ & $6.7 \mathrm{~b}$ & & & \\
\hline Pensacola & $8.6 \mathrm{a}$ & $8.7 \mathrm{a}$ & & & \\
\hline Funtastic $^{\mathrm{TM}}$ Fire Orange & $6.8 \mathrm{ab}$ & $4.0 \mathrm{c}$ & $3.7 \mathrm{a}$ & & \\
\hline Funtastic $^{\mathrm{TM}}$ Canary & $7.4 \mathrm{a}$ & $5.7 \mathrm{~b}$ & $4.2 \mathrm{a}$ & $3.3 \mathrm{a}$ & $2.8 \mathrm{a}$ \\
\hline $\operatorname{LSD}(P \leq 0.05)$ & 2.2 & 1.5 & 1.0 & 0.7 & 1.3 \\
\hline
\end{tabular}

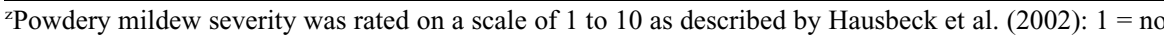
disease, $2=$ trace to $10 \%, 3=10 \%$ to $20 \%, 4=20 \%$ to $30 \%, 5=30 \%$ to $40 \%, 6=40 \%$ to $50 \%, 7=50 \%$ to $60 \%, 8=60 \%$ to $70 \%, 9=70 \%$ to $80 \%$, and $10=80 \%$ to $100 \%$ of leaf surface infected with powdery mildew.

y Values with the same letter within a column are not statistically different at $P \leq 0.05$.

LSD $=$ least significant difference.

The powdery mildew severity ratings of UFGE 7080 were similar to those of ' $F$ untastic ${ }^{\mathrm{TM}}$ Fire Orange' in all three experiments (Table 4). UFGE 7080 had less powdery mildew than
'Funtastic ${ }^{\mathrm{TM}}$ Canary' in Expts. 4 and 5 when disease pressure was high, but similar powdery mildew severity ratings in Expts. 6, 7, and 8 when disease pressure was relatively 
Table 5. Number of flowers produced per plant of UFGE 7031 and UFGE 7080 under natural powdery mildew disease pressures in comparison with 'Bimini', 'Pensacola', 'Funtastic ${ }^{\mathrm{TM}}$ Fire Orange', and/or 'Funtastic ${ }^{\mathrm{TM}}$ Canary' in four experiments conducted in Wimauma, FL (2009 and 2012).

\begin{tabular}{lcccr}
\hline Cultivars & $\begin{array}{c}\text { Expt. 4 (Jan. } \\
\text { to Mar. 2009) }\end{array}$ & $\begin{array}{c}\text { Expt. 5 (Apr. } \\
\text { to June 2009) }\end{array}$ & $\begin{array}{c}\text { Expt. 6 (Oct. } \\
\text { to Nov. 2009) }\end{array}$ & $\begin{array}{r}\text { Expt. 7 (June } \\
\text { to July 2012) }\end{array}$ \\
\hline UFGE 7031 & $4.6 \mathrm{c}^{\mathrm{z}}$ & $8.3 \mathrm{a}$ & $2.0 \mathrm{~b}$ & 6.0 \\
UFGE 7080 & $3.2 \mathrm{bc}$ & $5.0 \mathrm{~b}$ & $2.0 \mathrm{~b}$ & 6.0 \\
Bimini & $2.6 \mathrm{c}$ & $1.3 \mathrm{c}$ & & \\
Pensacola & $3.0 \mathrm{c}$ & $1.7 \mathrm{c}$ & & \\
Funtastic & $5.2 \mathrm{~b}$ & $11.3 \mathrm{a}$ & $5.3 \mathrm{a}$ & 6.5 \\
Funtastic Fire Orange & $7.4 \mathrm{a}$ & $9.3 \mathrm{a}$ & $4.2 \mathrm{a}$ & NS \\
LSD $(P \leq 0.05)$ & 2.0 & 3.4 & 1.3 &
\end{tabular}

${ }^{z}$ Values with the same letter within a column are not statistically different at $P \leq 0.05$.

LSD $=$ least significant difference; NS = not significantly different at $P \leq 0.05$.

low. These results indicate a moderate level of powdery mildew resistance in UFGE 7080. Again plants of UFGE 7080 produced fewer flowers than 'Funtastic ${ }^{\mathrm{TM}}$ Fire Orange' and 'Funtastic ${ }^{\mathrm{TM}}$ Canary' in the majority or all of the experiments (Table 5).

\section{Summary}

UFGE 7031 and UFGE 7080 produced attractive flowers and quality plants with peduncle and plant heights appropriate for use in large containers, and these new cultivars had many similar plant and flower characteristics compared with the existing Funtastic ${ }^{\mathrm{TM}}$ series bred and released for use in large containers. They have shown a moderate to high level of resistance to powdery mildew, a trait expected to be highly beneficial to greenhouse and nursery growers in reducing pesticide use and costs and for producing highly marketable finished potted gerbera. The powdery mildew resistance in these cultivars will likely be very beneficial to consumers in preventing significant damage from powdery mildew.
UFGE 7031 and UFGE 7080 tend to be somewhat slower than 'Funtastic ${ }^{\mathrm{TM}}$ Fire Orange' or 'Funtastic ${ }^{\mathrm{TM}}$ Canary' in leaf and flower development for the first 2 to 3 weeks after transplanting, resulting in fewer leaves and/or fewer flowers on finished potted plants. This crop-timing issue can be overcome by planting two tissue culture liners per container or planting one plug 2 weeks earlier than other Funtastic ${ }^{\mathrm{TM}}$ cultivars, so that production time would be similar to other cultivars in the Funtastic ${ }^{\mathrm{TM}}$ series.

Availability. The Florida Agricultural Experiment Station will apply for plant patents for UFGE 7031 and UFGE 7080. Production of these cultivars is to be with a licensing agreement with the Florida Foundation Seed Producers, Inc., P.O. Box 309, Greenwood, FL 32443. Information on propagation and/or production agreements can be obtained from the Florida Foundation Seed Producers, Inc. (<http://ffsp.net/>). UFGE 7031 and UFGE 7080 will be available under the name 'Funtastic ${ }^{\mathrm{TM}}$ Tangerine Eye' and 'Funtastic ${ }^{\mathrm{TM}}$ Golden Eye', respectively.

\section{Literature Cited}

Anonymous, 2011. OSU trials reveal top-performing annuals. GPN Greenhouse Product News. 3 Nov. 2012. <http://www.gpnmag.com/osu-trial-resultsreveal-top-performing-annuals $>$.

Behnke, M. 1984. Gerbera production. Grower Talks 47:94-97.

Channel, C. 2005. Gerbera trials rate plants. GM Pro 25:30-31.

Chase, A.R. 2001. 2001 Update on powdery mildew control. GPN-Greenhouse Product News 11:44-46.

Deng, Z. and B.K. Harbaugh. 2010. UFGE 4141, UFGE 7014, UFGE 7015, UFGE 7023, UFGE 7032, and UFGE 7034: Six new gerbera cultivars for marketing flowering plants in large containers. HortScience 45:971-974.

Dole, J.M. and H.F. Wilkins. 1999. Gerbera. In: Dole and Wilkins (ed.) Floriculture, principles and species. Prentice Hall, Upper Saddle River, NJ.

Hausbeck, M.K., W.R. Quackenbush, and S.D. Linderman. 2002. Evaluation of cultivars of African daisy for resistance to powdery mildew, 2002. B\&C Tests 18:00004.

Moyer, C. and N.A. Peres. 2008. Powdery mildew of gerbera daisy. 12 Nov. 2009. <http://edis. ifas.ufl.edu/pdffiles/PP/PP25700.pdf $>$.

Price, J.F., C. Nagle, and E. McCord, Jr. 2003. Insect and mite management suggestions for commercial gerbera production. 12 Nov. 2009. <http:// edis.ifas.ufl.edu/pdffiles/IG/IG00400.pdf>.

Rogers, M.N. and B.O. Tjia. 1990. Gerbera production for cut flowers and pot plants. Timber Press, Portland, OR.

Royal Horticultural Society. 1986. Royal Horticultural Society colour chart. Royal Hort. Soc., London, UK.

Siktberg, R. 2012. The newest trends for blooming potted plants. Greenhouse Grower. 3 Nov. 2012. <http://www.greenhousegrower.com/ article/24710/the-newest-trends-for-bloomingpotted-plants $>$. 